\title{
Ice motion and mass balance at the Allan Hills blue-ice area, Antarctica, with implications for paleoclimate reconstructions
}

\author{
Nicole E. SPAULDING, ${ }^{1,2}$ Vandy B. SPIKES, ${ }^{3}$ Gordon S. HAMILTON, ${ }^{1,2}$ \\ Paul A. MAYEWSKI, ${ }^{1,2}$ Nelia W. DUNBAR, ${ }^{4}$ Ralph P. HARVEY, ${ }^{5}$ John SCHUTT, ${ }^{5}$ \\ Andrei V. KURBATOV ${ }^{1}$ \\ ${ }^{1}$ Climate Change Institute, University of Maine, Orono, ME, USA \\ E-mail: nicole.spaulding@maine.edu \\ ${ }^{2}$ Department of Earth Science, University of Maine, Orono, ME, USA \\ ${ }^{3}$ Earth Science Agency LLC, Stateline, NV, USA \\ ${ }^{4}$ New Mexico Institute of Mining and Technology, Socorro, NM, USA \\ ${ }^{5}$ Department of Geological Sciences, Case Western Reserve University, Cleveland, OH, USA
}

\begin{abstract}
We present a new surface-balance and ice-motion dataset derived from high-precision GPS measurements from a network of steel poles within three icefields of the Allan Hills blue-ice area, Antarctica. The surveys were conducted over a 14 year time period. Ice-flow velocities and massbalance estimates for the main icefield (MIF) are consistent with those from pre-GPS era measurements but have much smaller uncertainties. The current study also extends these measurements through the near-western icefield (NWIF) to the eastern edge of the mid-western icefield (MWIF). The new dataset includes, for the first time, well-constrained evidence of upward motion within the Allan Hills MIF, indicating that old ice should be present at the surface. These data and terrestrial meteorite ages suggest that paleoclimate reconstructions using the surface record within the Allan Hills MIF could potentially extend the ice-core-based record beyond the $\mathbf{8 0 0 0 0 0}$ years currently available in the EPICA Dome C core.
\end{abstract}

\section{INTRODUCTION}

The recognition of blue-ice areas (BIAs) as archives of long climate records is based on the pioneering work of Whillans and Cassidy (1983) and subsequent work by Grinsted and others (2003), Moore and others (2006) and Sinisalo and others (2007). BIAs are anomalous mass-loss regions within the accumulation zones of ice sheets that owe their origin to a combination of slow-moving ice, steep topography and strong winds in the vicinity of nunataks (Bintanja, 1999). As mountains or nunataks block ice flow, glacial ice is projected upward, creating steeply sloped surfaces that enhance local katabatic (or gravity-driven) winds. Ice downslope is subjected to intense and prolonged ablation, causing inclined strata of old ice to outcrop at the surface. Several studies point to the possibility that ice exposed at the surface in the Allan Hills (Antarctica) BIA $\left(76^{\circ} 43^{\prime} \mathrm{S}, 159^{\circ} 40^{\prime} \mathrm{E}\right.$; Fig. 1$)$ is as old as $1 \mathrm{Ma}$. This estimate is based on terrestrial ages from $\sim 100$ of the $\sim 1500$ meteorites found in the area (Nishiizumi and others, 1989; Scherer and others, 1997; Mokos and others, 2000; Nishiizumi, 2006; Nishiizumi and Welten, 2008). In addition, ages from a layer of micrometeoritic debris found embedded in the ice of the Allan Hills main icefield (MIF) suggest stranded ice as old as 2.5 Ma is also present (Harvey and others, 1998). Whillans and Cassidy (1983) predicted that ice in the Allan Hills would flow from the mid-western icefield (MWIF) through the near-western icefield (NWIF) into the MIF, with ice and meteorites being exposed on each icefield, buried by new snow accumulation when flowing through the downstream snow plains and re-exposed at the next icefield. This pattern suggests that the oldest ice and thus the longest climate record should be found in the MIF.

To better understand ice flow and mass balance within the Allan Hills BIA, a multi-year precision GPS survey was undertaken. Measurements from this survey are used to provide a framework for the identification of a predicted flowline within the MIF along which ice of sequential age can be collected, and to test the feasibility of developing paleoclimate records from the Allan Hills using the horizontal coring method proposed by Whillans and Cassidy (1983). Many important insights into climate dynamics have come from deep ice cores including: the responsiveness of global climate to changes in orbitally induced insolation patterns (e.g. Kawamura and others, 2007; Suwa and Bender, 2008); the role of volcanic forcing (Gao and others, 2008); the identification of abrupt high-magnitude changes in climate (Dansgaard and others, 1993; Grootes and others, 1993; Mayewski and others, 1994); and the close association between atmospheric greenhouse gases and temperature (EPICA Community Members, 2004). However, the longest ice-core-based climate record covers only the last 800000 years, and resolution and sample volume are limited, particularly in deep time (Jouzel and others, 2007). Horizontal cores from the Allan Hills BIA could both extend this record and augment it through increased sample volume.

\section{Site description}

The Allan Hills are located on the western flank of a portion of the Transantarctic Mountains known as the Convoy Range (Fig. 1c). This range is a barrier to ice flow that drains the East Antarctic ice sheet into the Mawson and Mackay outlet glaciers (Fig. 1a and e). Three icefields situated just west of the Allan Hills nunatak and between the two outlet glaciers are the focus of this study. Together, the MIF, NWIF and MWIF consist of $\sim 200 \mathrm{~km}^{2}$ of exposed blue ice separated by snow plains that are usually underlain by firn (Cassidy and others, 1992). The position of these icefields between two 

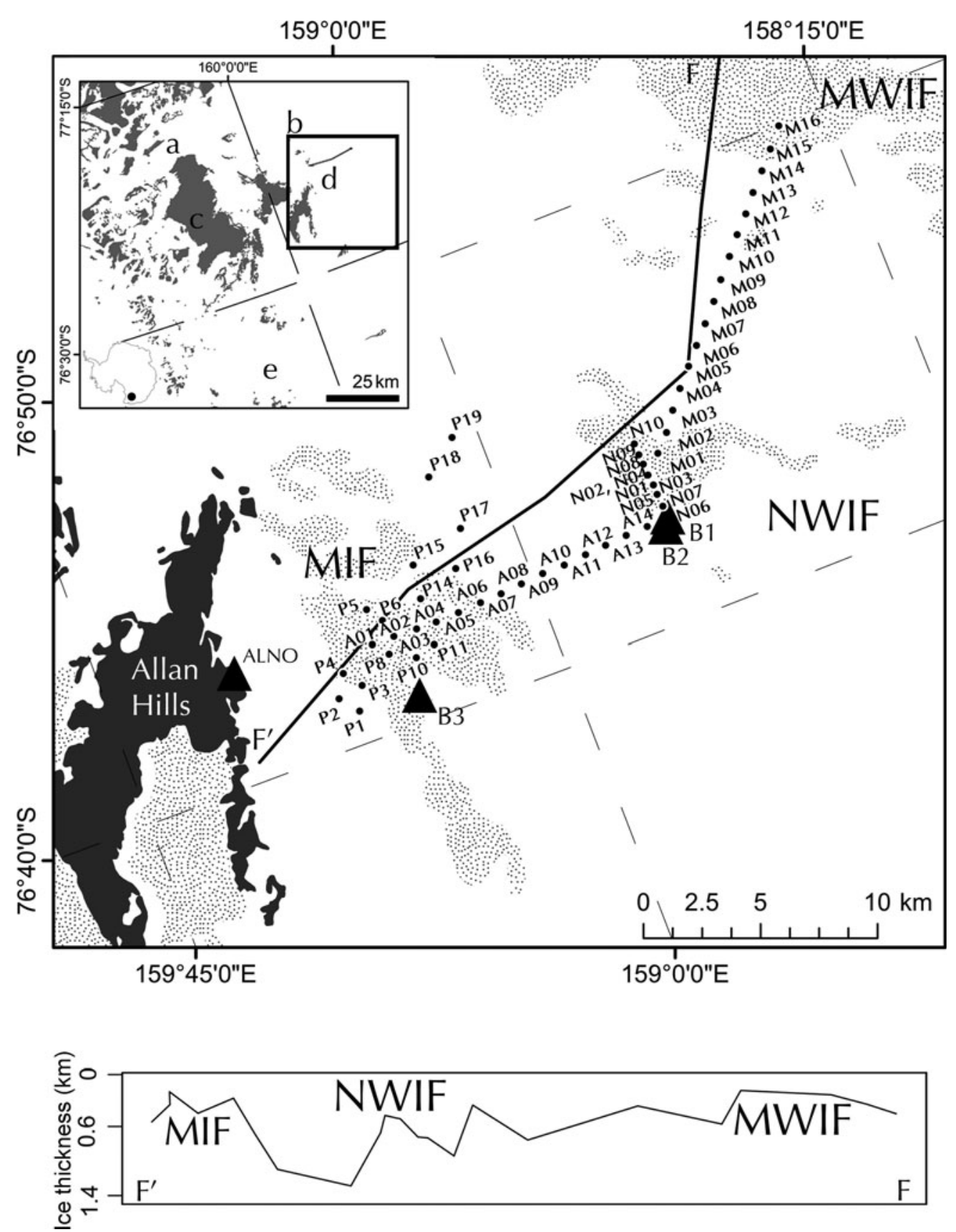

Fig. 1. The Allan Hills BIA (roughly bounded by square b within the inset) comprises four icefields separated by snow plains. The $200 \mathrm{~km}^{2}$ of exposed blue ice in the MIF, NWIF and MWIF (stippled areas) are shown. The extent of exposed blue ice within each icefield is based on Advanced Spaceborne Thermal Emission and Reflection Radiometer (ASTER) images from November 2001; snow cover is known to change seasonally and annually. The locations of a network of steel poles established in 1997 (prefix A and M) and augmented in 2004 (prefix P), as well as geodetic control points (ALNO, B1, B2 and B3) are shown. Within the inset the locations of the surrounding Convoy Range (c), Mawson (a) and Mackay (e) Glaciers and a local ice divide (d) are indicated. Ice thickness (shown at the bottom) along line F- $\mathrm{F}^{\prime}$ is derived using figures 1 and 5 of Delisle and Sievers (1991).

outlet glaciers puts them very close to a local ice divide (Fig. 1d), which can be used to constrain the location of the accumulation area of the MIF under present conditions.

Surveys of subglacial topography have been carried out using radar (Faure and Buchanan, 1987; Delisle and Sievers, 1991) and gravity (Fudali, 1982, 1989) measurements. The measurements of Delisle and Sievers (1991), reproduced in Figure 1 along transect $\mathrm{F}-\mathrm{F}^{\prime}$, show that maximum ice thickness under any blue-ice surface is generally no more than $400 \mathrm{~m}$. Thicker ice with snow cover is prevalent in the subglacial troughs between the BIAs. The ice thickness between the MWIF and the NWIF ranges from 200 to
$1200 \mathrm{~m}$, with a typical thickness of $>300 \mathrm{~m}$. Ice thicknesses between the NWIF and the MIF are typically $>1000 \mathrm{~m}$ because of a deep bedrock trough that opens up to the north (Delisle and Sievers, 1991).

\section{METHODS}

A network of 40 steel poles extending $40 \mathrm{~km}$ west from the base of the Allan Hills nunatak was established in December 1997 and augmented with an additional 15 poles in January 2004 (Fig. 1). Metal poles $3 \mathrm{~m}$ in length were inserted at least $1 \mathrm{~m}$ deep into hand-augered vertical holes in the snow and 
ice. Each pole was surveyed four times over the $\sim 14$ year time period using a dual-frequency Trimble 4000 series (1997, 1999, 2004) or Trimble 5700 (2010) GPS receiver and stop-and-go kinematic $(1997,1999,2004)$ and fast-static (2010) survey methods in order to determine precise pole position. These positions were used to calculate vertical and horizontal ice velocities and changes in surface elevations.

Geodetic control was provided by a reference GPS station (ALNO) set up on the Allan Hills nunatak (Fig. 1) in 1997. Its position was computed using the NASA Jet Propulsion Laboratory's Automatic Precise Positioning Service (APPS), a GPS inferred positioning system (GIPSY). Trimble GPSurvey software was used to calculate five baselines between ALNO and an additional GPS station on the ice (B1) over a 5 day period. A mean position for B1 was calculated from those baselines. In 1999, 2004 and 2010 no reference receiver was set up on the Allan Hills nunatak; rather, GIPSY was used to determine the position of a base station installed on the ice (B2, B3) throughout each season and the calculated mean position was used as the fixed base-station position. Daily and mean positions used for each season are summarized in table S1 available from the US National Snow and Ice Data Center at http://nsidc.org/data/nsidc0507.html. All supplementary tables and data are available for download from that site.

In 1999, 2004 and 2010, subsets of the pole network were resurveyed and Trimble software was used to calculate pole positions relative to the fixed base station adopted for each season. Precise ephemerides were used during postprocessing. The position accuracy of each pole was variable around a mean three-dimensional rms (root mean square encompassing vertical and horizontal position) of $0.013 \mathrm{~m}$. The initial and final position of each pole and a complete error report for each position are available in tables S2 and S3, respectively, at http://nsidc.org/data/nsidc-0507.html. The height of each pole above the snow or ice surface was also recorded in December 1997, December 1999, January 2004 and December 2010. Pole positions and heights were used to determine horizontal and vertical ice-flow vectors, as well as net accumulation rates.

During the 1999 and 2004 seasons the topography of the region was mapped using kinematic GPS surveying techniques. The average rms error for each kinematic segment was $0.12 \mathrm{~m}$. Elevation contours were produced by gridding and resampling kinematic GPS data to a $50 \mathrm{~m}$ spacing using a nearest-neighbor algorithm within the Spatial Analyst toolbox of ArcMap 10. The contours were used to calculate the slope in the direction of ice flow for each pole.

\section{RESULTS}

Table 1 summarizes the measurements at each of the poles. The mean and maximum rms for horizontal motion are 0.003 and $0.007 \mathrm{~m} \mathrm{a}^{-1}$, respectively. Larger uncertainties occur when baselines are longer than $10 \mathrm{~km}$, when there is multipath interference from the blue-ice surface or ice ridges obscure satellites low to the horizon, or when the time between surveys is short. Ice-flow velocities and directions found on the MIF are consistent with an earlier study by Schultz and others (1990) who determined that ice enters the MIF from the southwest at $0.60 \mathrm{~m} \mathrm{a}^{-1}$ and decreases to nearly zero at the nunatak. Horizontal velocity vectors and surface contours suggest that ice might flow from the MWIF to the NWIF, but that it does not flow from the NWIF to the
MIF as predicted by Whillans and Cassidy (1983) due to the subglacial bedrock trough that separates these icefields and directs ice flow to the north (Figs 2 and 3).

The mean and maximum rms for vertical motion are 0.011 and $0.033 \mathrm{~m} \mathrm{a}^{-1}$, respectively. Uncertainties in firn density make the vertical velocities of the poles in the snow plains subject to large errors; however, the upward motion of the poles within the icefields is well constrained. Of the 12 poles installed in blue ice, 11 have upward flow velocities higher than the associated error (Fig. 4).

Ablation rate measurements from the current study agree well with values reported by earlier studies (Nishio and Annexstad, 1980; Annexstad and Schultz, 1983; Shultz and Annexstad, 1984; Faure and Buchanan, 1987) in which it was established that most of the ablation occurs during the summer months. Ablation rates range from $0.046 \pm 0.003$ $\mathrm{ma}^{-1}$ near the western flank of the Allan Hills nunatak to $0.03 \pm 0.003 \mathrm{~m} \mathrm{a}^{-1}$ near the western boundary of the MIF. The NWIF has a mean ablation of $0.026 \pm 0.003 \mathrm{~m} \mathrm{a}^{-1}$. The only pole installed on the MWIF has an ablation rate of $0.009 \pm 0.003 \mathrm{~m} \mathrm{a}^{-1}$. Measurements of accumulation rate in the snow plains are highly variable as both the presence of large migrating sastrugi (up to $1 \mathrm{~m}$ high), formed by katabatic winds, and seasonal and annual variability in the strength and direction of surface winds cause short-term fluctuations in the apparent accumulation rate at each pole. These complex wind patterns also result in the formation of small patches of blue ice and firn within the snow plains, often partially covered by new snow and/or sastrugi.

\section{DISCUSSION}

\section{Blue-ice dynamics}

The data in Table 1 were used to calculate the rate of thickness change $\dot{H}\left(\mathrm{~m} \mathrm{a}^{-1}\right)$ by:

$$
\dot{H}=\frac{\dot{b}_{m}}{\rho}+\dot{z}+\alpha u
$$

where $\dot{b}_{m}$ is the net accumulation rate $\left(\mathrm{Mg} \mathrm{m}^{-2} \mathrm{a}^{-1}\right), \rho$ is the density of the material to which the movement marker is attached $\left(\mathrm{Mg} \mathrm{m}^{-3}\right), \dot{z}$ is the vertical velocity $\left(\mathrm{ma}^{-1}\right)$ of the marker, $\alpha$ is the surface slope in the direction of ice flow (rad; positive downward) and $u$ is the horizontal velocity $\left(\mathrm{m} \mathrm{a}^{-1}\right)$. This so-called 'coffee-can method' is described in more detail by Hulbe and Whillans (1994) and Hamilton and others (1998).

$\dot{H}$ and the associated uncertainties for all poles are presented in Table 1 (see details in table S4 at http:// nsidc.org/data/nsidc-0507.html). Variability in the density of snow is one of the largest contributors to errors when using the coffee-can method. The density of ice is well known and the value $0.90 \pm 0.01 \mathrm{Mg} \mathrm{m}^{-3}$ was used for poles installed in blue ice. To establish the average density for new snow and firn in this area, ten $1 \mathrm{~m}$ cores were drilled up- and downglacier of the NWIF in 1999. The cores were cut into segments ranging from 10 to $20 \mathrm{~cm}$. The length, diameter and mass were recorded for each segment. The density of each segment was then calculated to determine how the snow density changed with depth (core location and depth profile available in Spikes (2000) and also as a supplementary data file). An average surface density of $0.40 \pm 0.10 \mathrm{Mg} \mathrm{m}^{-3}$ was used to calculate the ice equivalent accumulation for each pole in snow plains. An average $1 \mathrm{~m}$ density of 
Table 1. GPS-based measurements for each pole. Measurements for poles located on blue ice and firn (as opposed to snow plains) are shown in bold. Headings are as in the text where $u$ is horizontal velocity, Azimuth is direction of motion, $\dot{z}$ is vertical velocity, $\dot{b}_{m}$ is net accumulation rate, $\alpha$ is surface slope in the direction of ice flow (positive downward) and $\dot{H}$ is rate of thickness change. $\dot{b}_{m}$ and $\dot{H}$ are omitted for the snow plains because of high uncertainty

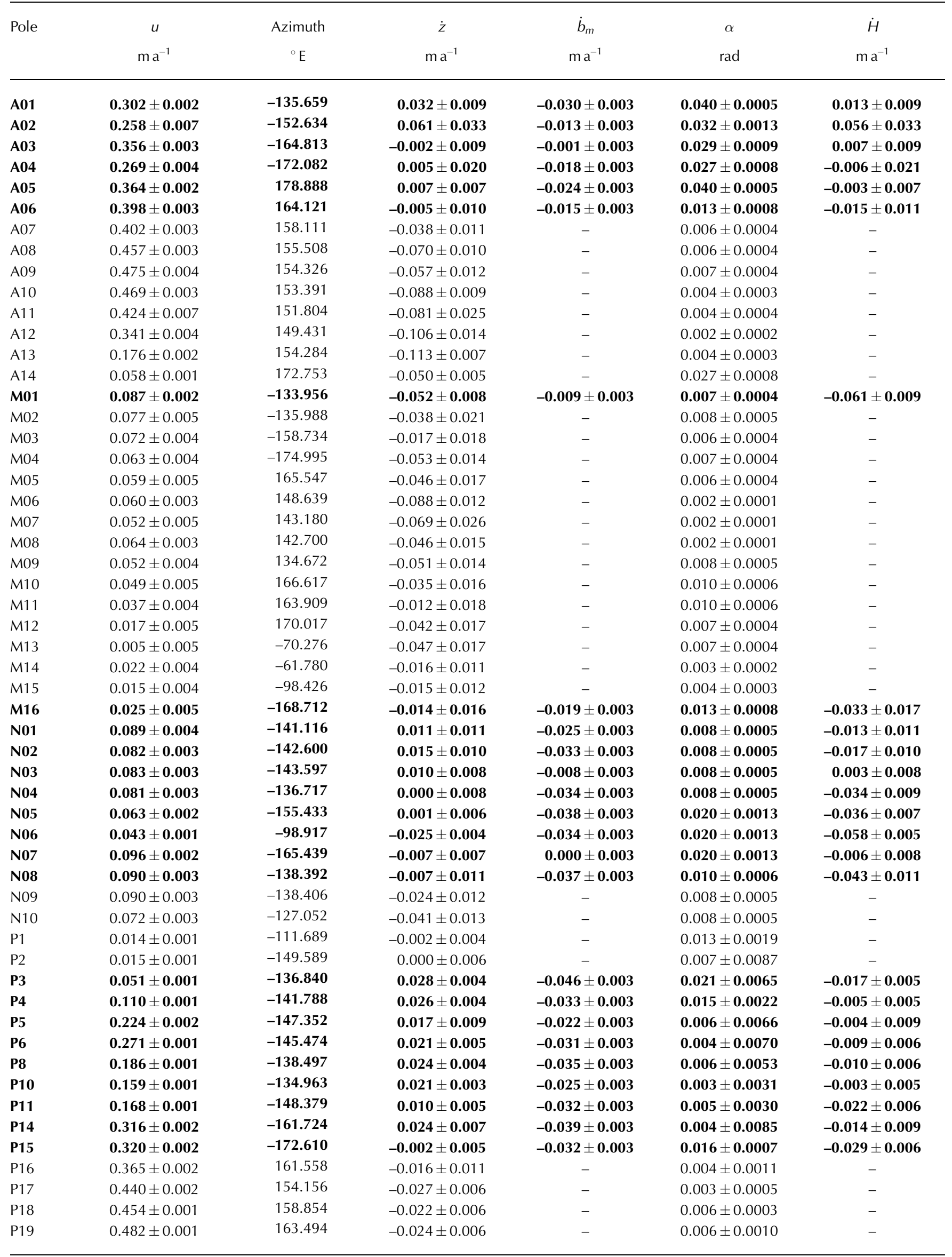




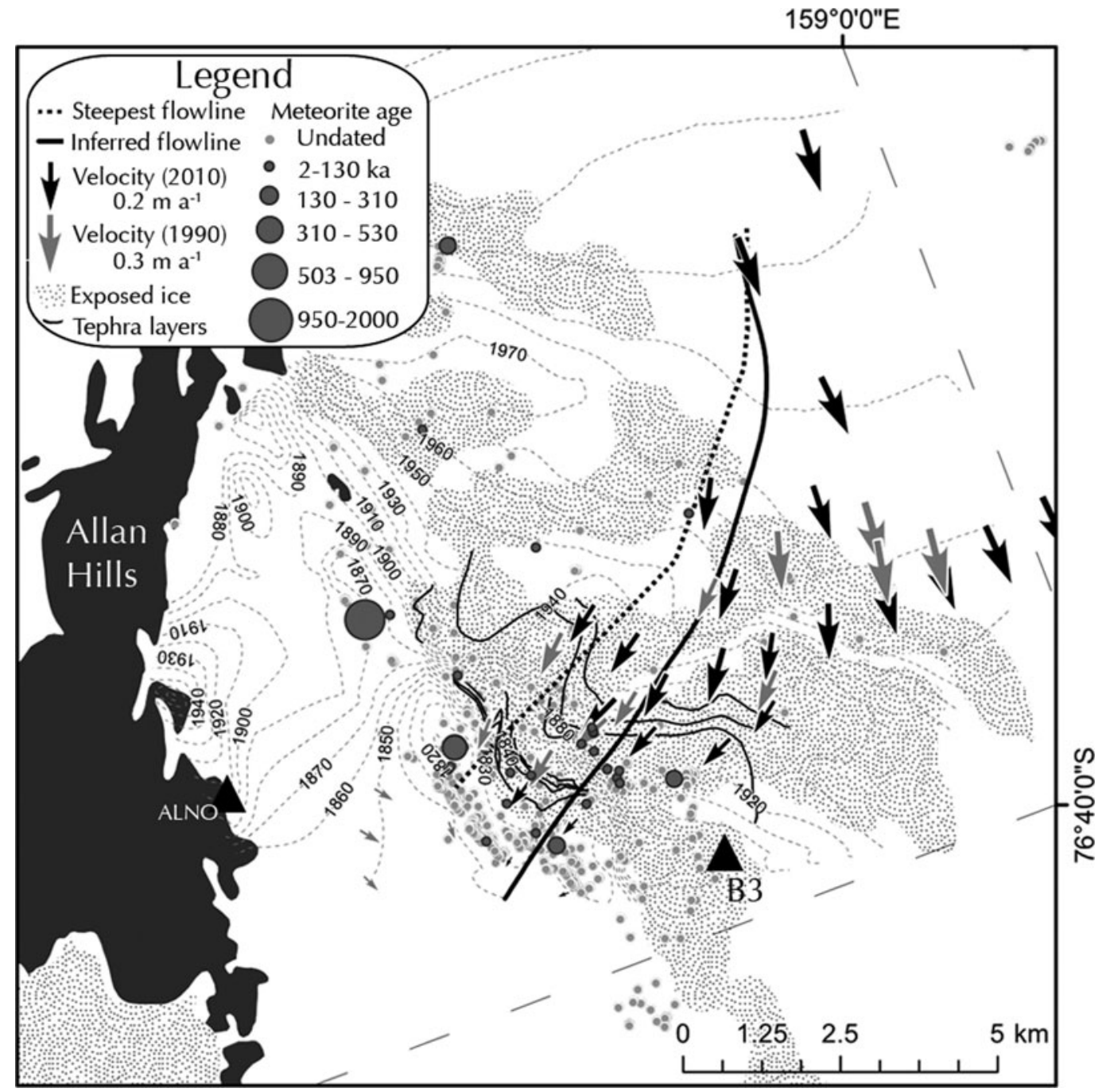

Fig. 2. Horizontal ice-flow velocity vectors as determined using repeat precision GPS survey. The steel poles are located in the center of each arrow. ALNO and B3 are geodetic control points. Elevation is reported in ma.s.l. with a contour interval of $10 \mathrm{~m}$ and a vertical resolution of $25 \mathrm{~cm}$ or better. Contouring includes only the area covered during GPS surveys in 2004. 1990 velocities from figure 1 of Schultz and others (1990). Tephra layers from Dunbar and others (1995).

$0.47 \pm 0.10 \mathrm{Mg} \mathrm{m}^{-3}$ was used to estimate the amount of vertical movement caused by compaction of the snow under each pole in the snow plains. These data indicate that the Allan Hills icefields are thinning on average by $1.5 \pm 1.0 \mathrm{~cm} \mathrm{a}^{-1}$. $\dot{H}$ was not calculated for the surrounding snow plains due to large errors in density and accumulation at these locations. The slow thinning rate is consistent with a negative mass balance suggested by Bintanja (1999). This thinning is likely balanced by thickening of the snow plains, suggesting steady-state conditions and long-term continuity of the icefields as a whole. The rate of thinning and high rates of ablation within the icefields are good indicators that old ice should be found at the surface in the MIF.

Previous models have proposed an upward flow component in ablation settings due to longitudinally compressive ice flow (Whillans and Cassidy, 1983). However, all previously reported emergence velocities (Nishio and Annexstad, 1980) have had associated errors too large to confirm the presence of upward motion. In the MWIF and NWIF the pattern of horizontal speed change is generally extensive and, as a result, most of the measured vertical motions are downward (Fig. 4). Four poles crossing the NWIF were placed perpendicular to a dust band described by Delisle and Sievers (1991) as resulting from the vertical flow of ice up a steep subglacial escarpment. Derived vertical velocities for the poles only provide weak support for vertical shearing along a discrete fault plane, being in the range $0.001 \pm 0.006$ to $0.015 \pm 0.010$. The uncertainties are relatively large due to the short 2 year period of observations. Flow within the MIF is largely compressive and 11 of the 12 poles installed in blue ice have upward flow velocities greater than the associated error. These measurements further indicate that old ice is exposed at the surface of the Allan Hills MIF.

Calculated horizontal velocities suggest that there are two distinct flow regimes operating within the study area (Figs 2 and 3$)$. The first is the very slow flow $\left(<10 \mathrm{~cm} \mathrm{a}^{-1}\right)$ characteristic of BIAs (bold in Table 1) and is controlled by the presence of shallow bedrock ridges. The other flow regime is a faster-moving outlet channel $\left(\sim 50 \mathrm{~cm} \mathrm{a}^{-1}\right)$ between the NWIF and MIF. The impact of bedrock topography within the Allan Hills on surface ice velocities provides support for the presence of old ice in BIAs (Whillans and Cassidy, 1983) as ablation of nearly stagnant ice is matched by vertical velocity. Enhanced ablation rates are also the result of bedrock topography as, where ice is relatively thin, 


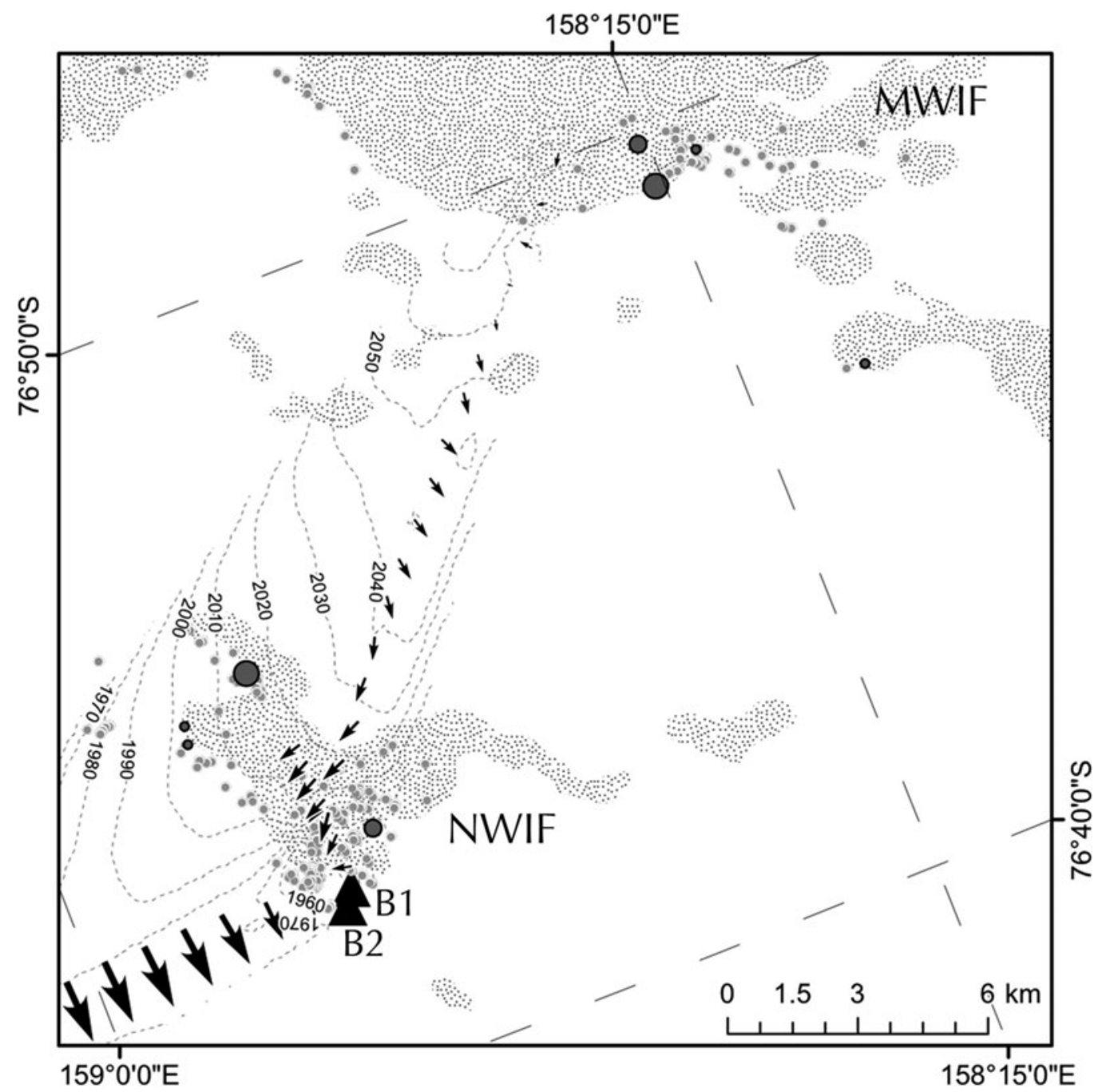

Fig. 3. Horizontal ice-flow velocity vectors as determined using repeat precision GPS survey. The steel poles are located in the center of each arrow. B1 and B2 are geodetic control points. Elevation is reported in ma.s.l. with a contour interval of $10 \mathrm{~m}$ and a vertical resolution of $25 \mathrm{~cm}$ or better. Contouring includes only the area covered during GPS surveys in 1999. See Figure 2 for legend.

surface slope on the leeward side of a subsurface obstruction will steepen, enhancing local katabatic winds.

\section{Implications for paleoclimate reconstructions}

Beyond helping to understand the origin of BIAs this dataset can be used to potentially extend the ice-core-based paleoclimate record. Although ice does not flow from the MWIF through the NWIF and into the MIF as previously assumed, near-stagnant ice, upward vertical motion and a higher concentration of older meteorites suggest that the MIF is the most likely of the three icefields to contain very old ice. The horizontal velocity vectors and surface topography are used to identify a zone within the MIF in which ice of sequential age can be collected. This zone is demarcated to the east by a flow path derived using only the digital elevation model (DEM) and the cost-path algorithm in the Spatial Analyst toolbox of ArcMap 10 (Fig. 2, steepest flowline). Small-scale deviations $(<1000 \mathrm{~m})$ from the primary direction were removed to produce a general (simplified) line. Although surface slope is the driving factor of ice flow, ice thickness is also important (Paterson, 1994), so a second flow path was derived using both the elevation contours, estimates of ice thickness and vectors of horizontal motion (Fig. 2, inferred flowline). This flow path demarcated the western boundary of the identified flow zone. The continuity of tephra layers within the identified flow zone (Dunbar and others, 1995) rules out the occurrence of significant brittle deformation, resulting in offsetting of layers, although thinning of the ice column has probably taken place. Thus, future sampling efforts for paleoclimate reconstruction should be conducted within this zone.

\section{CONCLUSIONS}

Repeat GPS measurements over a $\sim 14$ year time period yielded well-constrained estimates of present-day horizontal and vertical velocities, accumulation/ablation rates and rates of thickness change in the Allan Hills BIA. Horizontal velocities agree well with previous studies using traditional survey methods and appear to indicate flow controlled by bedrock topography. For the first time, reliable measurements of upward motions were obtained from a BIA, thus supporting the hypothesized presence of old ice at the surface. The surface-balance measurements reveal a complex pattern of accumulation/ablation that is probably related to the interaction of ice flow with seasonally variable surface wind patterns. Blue ice and adjacent firn areas are thinning at an average rate of $1.5 \pm 1.0 \mathrm{~cm} \mathrm{a}^{-1}$, 


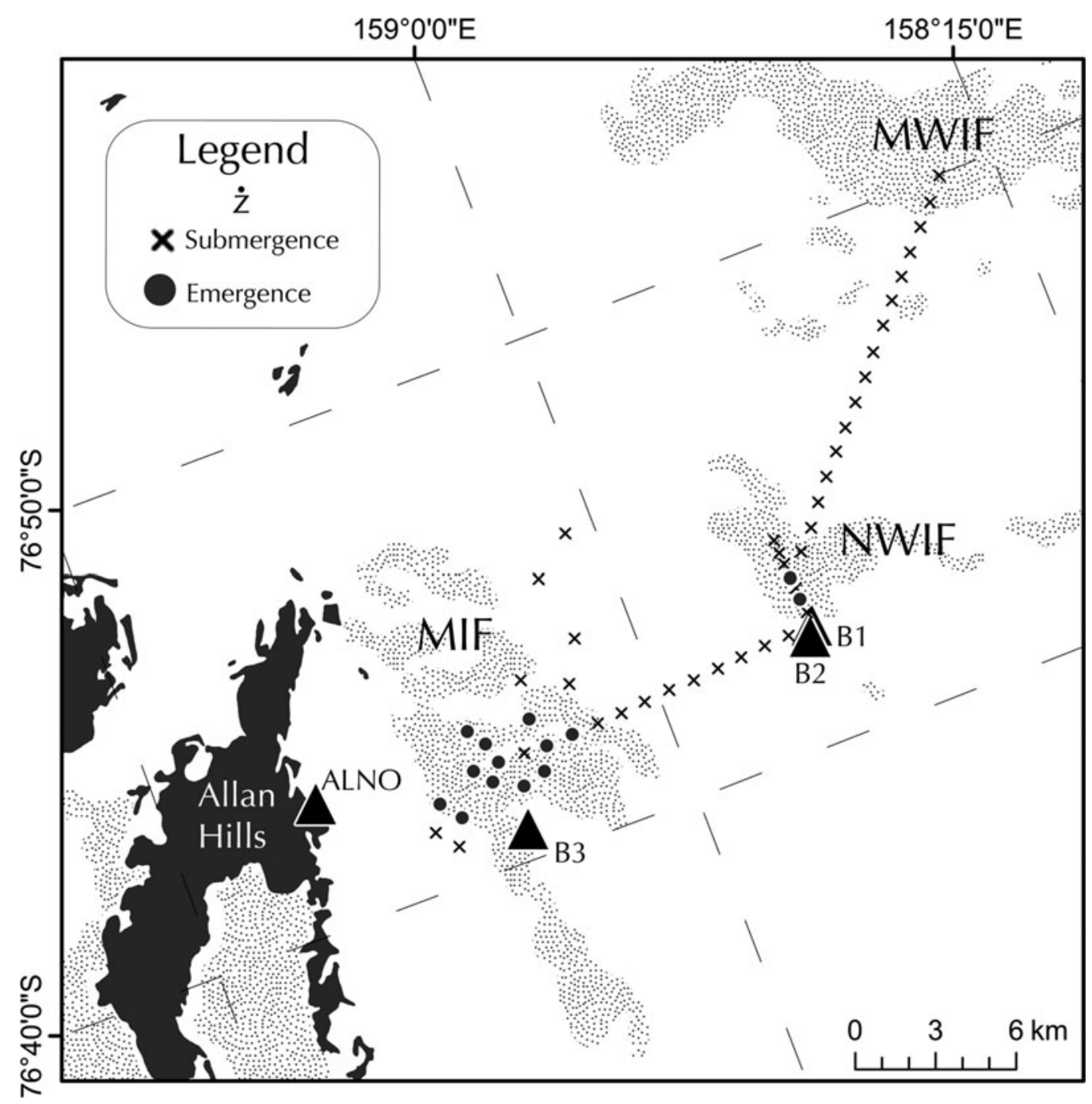

Fig. 4. Vertical velocities were determined using repeat precision GPS surveys. Emergence $(\dot{z})$ velocities were found both on the MIF and the NWIF. ALNO, B1, B2 and B3 are geodetic control points.

which appears to be offset by thickening in the adjacent snow plains. These data suggest that steady-state conditions enable the long-term continuity of the Allan Hills BIA. All glaciological observations and meteorite ages point to the presence of old ice at the surface in the MIF, and analysis of these data was used to identify a flow zone in the MIF within which ice for paleoclimate studies of deep time can be collected.

\section{ACKNOWLEDGEMENTS}

We thank John Annexstad, Georg Delisle, Ludolf Schultz, John Moore and the late Ian Whillans for their work in the Allan Hills and other BIAs and their willingness to share data from those expeditions. We acknowledge field assistance from Mike Waszkiewicz, Kristin Schild, Melissa Rohde, Erik Venteris and Leigh Stearns; GIS support from Spencer Niebuhr of the Antarctic Geospatial Information Center; and GPS support from Joe Pettit, Marianne Okal and Lisa Siegel of the University Navstar Consortium (UNAVCO). The logistic support provided by Raytheon Polar Services and field transportation by the Twin Otter pilots of Kenn Borek Air Ltd were indispensable. The manuscript was greatly improved by helpful comments from two anonymous reviewers. Funding for this research was provided by the US National Science Foundation Office of Polar Programs through grants 0838843,0229245 and 9527571.

\section{REFERENCES}

Annexstad JO and Schultz L (1983) Measurements of the triangulation network at the Allan Hills meteorite icefield. In Oliver RL, James PR and Jago JB eds. Antarctic earth science. Cambridge University Press, Cambridge, 617-619

Bintanja R (1999) On the glaciological, meteorological and climatological significance of Antarctic blue ice areas. Rev. Geophys., 37(3), 337-359

Cassidy WA, Harvey R, Schutt J, Delisle G and Yanai K (1992) The meteorite collection sites of Antarctica. Meteoritics, 27(5), 490-525

Dansgaard W and 10 others (1993) Evidence for general instability of past climate from a 250-kyr ice-core record. Nature, 364(6434), 218-220

Delisle G and Sievers J (1991) Subice topography and meteorite finds near the Allan Hills and the near Western Icefield, Victoria Land, Antarctica. J. Geophys. Res., 96(E1), 15 577-15 587

Dunbar NW, Kyle PR, McIntoch WC and Esser RP (1995) Allan Hills, Antarctica: a new source of glacial tephrochronological data. Antarct. J. US, 30(5), 76-78 
EPICA Community Members (2004) Eight glacial cycles from an Antarctic ice core. Nature, 429(6992), 623-628 (doi: 10.1038/ nature02599)

Faure G and Buchanan D (1987) Glaciology of the East Antarctic ice sheet at the Allan Hills: a preliminary interpretation. Antarct. J. US, 22(5), 74-75

Fudali RF (1982) Gravity measurements across the Allan Hills main meteorite collecting area. Antarct. J. US, 17(5), 58-60

Fudali RF (1989) Gravity measurements across and between the meteorite-bearing icefields west-southwest of the Allan Hills. Antarct. J. US, 24(5), 48-50

Gao C, Robock A and Ammann C (2008) Volcanic forcing of climate over the past 1500 years: an improved ice corebased index for climate models. J. Geophys. Res., 113(D23), D23111

Grinsted A, Moore JC, Spikes VB and Sinisalo A (2003) Dating Antarctic blue ice areas using a novel ice flow model. Geophys. Res. Lett., 30(19), 2005 (doi: 10.1029/2003GL017957)

Grootes PM, Stuiver M, White JWC, Johnsen S and Jouzel J (1993) Comparison of oxygen isotope records from the GISP2 and GRIP Greenland ice cores. Nature, 366(6455), 552-554

Hamilton GS, Whillans IM and Morgan PJ (1998) First point measurements of ice-sheet thickness change in Antarctica. Ann. Glaciol., 27, 125-129

Harvey RPand 6 others (1998) Meteoritic event recorded in Antarctic ice. Geology, 26(7), 607-610 (doi: 10.1130/0091-7613(1998) 026<0607:MERIAI >2.3.CO;2)

Hulbe CL and Whillans IM (1994) A method for determining icethickness change at remote locations using GPS. Ann. Glaciol., 20, 263-268

Jouzel J and 31 others (2007) Orbital and millennial Antarctic climate variability over the past 800,000 years. Science, 317(5839), 793-796 (doi: 10.1126/science.1141038)

Kawamura K and 17 others (2007) Northern Hemisphere forcing of climatic cycles in Antarctica over the past 360,000 years. Nature, 448(7156), 912-916 (doi: 10.1038/nature06015)

Mayewski PA and 13 others (1994) Changes in atmospheric circulation and ocean ice cover over the North Atlantic during the last 41,000 years. Science, 263(5154), 1747-1751

Mokos JL, Franke L, Scherer P, Schultz L and Lipschutz ME (2000) Cosmogenic radionuclides and noble gases in Antarctic $\mathrm{H}$ chondrites with high and normal natural thermoluminescence levels. Meteorol. Planet. Sci., 35(4), 713-721 (doi: 10.1111/ j.1945-5100.2000.tb01455.x)

Moore JC and 7 others (2006) Interpreting ancient ice in a shallow ice core from the South Yamato (Antarctica) blue ice area using flow modeling and compositional matching to deep ice cores. J. Geophys. Res., 111(D16), D16302 (doi: 10.1029/ 2005JD006343)

Nishiizumi K (2006) Terrestrial age survey of Antarctic meteorites. Antarct. Meteorol. Newsl., 29(1), 3-4

Nishiizumi K and Welten K (2008) Terrestrial age survey of Antarctic meteorites. Antarct. Meteorol. Newsl., 31(1), 7-8

Nishiizumi K, Elmore D and Kubik PW (1989) Update on terrestrial ages of Antarctic meteorites. Earth Planet. Sci. Lett., 93(3-4), 299-313

Nishio F and Annexstad JO (1980) Studies on the ice flow in the bare ice area near the Allan Hills in Victoria Land, Antarctica. Mem. Natl Inst. Polar Res., Special Issue 17, 1-13

Paterson WSB (1994) The physics of glaciers, 3rd edn. Elsevier, Oxford

Scherer P and 11 others (1997) Allan Hills 88019: an Antarctic $\mathrm{H}$-chondrite with a very long terrestrial age. Meteorol. Planet. Sci., 32(6), 769-773 (doi: 10.1111/j.1945-5100.1997.tb01567.x)

Schultz L and Annexstad JO (1984) Ablation and ice movement at the Allan Hills main icefield between 1978 and 1981. Smithsonian Contrib. Earth Sci. 26, 17-22

Schultz L, Annexstad JO and Delisle G (1990) Ice movement and mass balance at the Allan Hills Icefield. Antarct. J. US, 25(5) 94-95

Sinisalo A, Grinsted A, Moore JC, Meijer HAJ, Martma Tand Van de Wal RSW (2007) Inferences from stable water isotopes on the Holocene evolution of Scharffenbergbotnen blue-ice area, East Antarctica. J. Glaciol., 53(182), 427-434 (doi: 10.3189/ 002214307783258495)

Spikes VB (2000) Laser altimetry, mass balance, and meteorites: a two part study of ice streams and blue ice. (Master's thesis, Ohio State University)

Suwa M and Bender ML (2008) Chronology of the Vostok ice core constrained by $\mathrm{O}_{2} / \mathrm{N}_{2}$ ratios of occluded air, and its implication for the Vostok climate records. Quat. Sci. Rev., 27(11-12), 1093-1106 (doi: 10.1016/j.quascirev.2008.02.017)

Whillans IM and Cassidy WA (1983) Catch a falling star: meteorites and old ice. Science, 222(4619), 55-57 